ITLV/10972--208

UC-700

\title{
Evaluation of the
}

Rulison Drilling Effluent Pond as Trout Habitat

February 1997

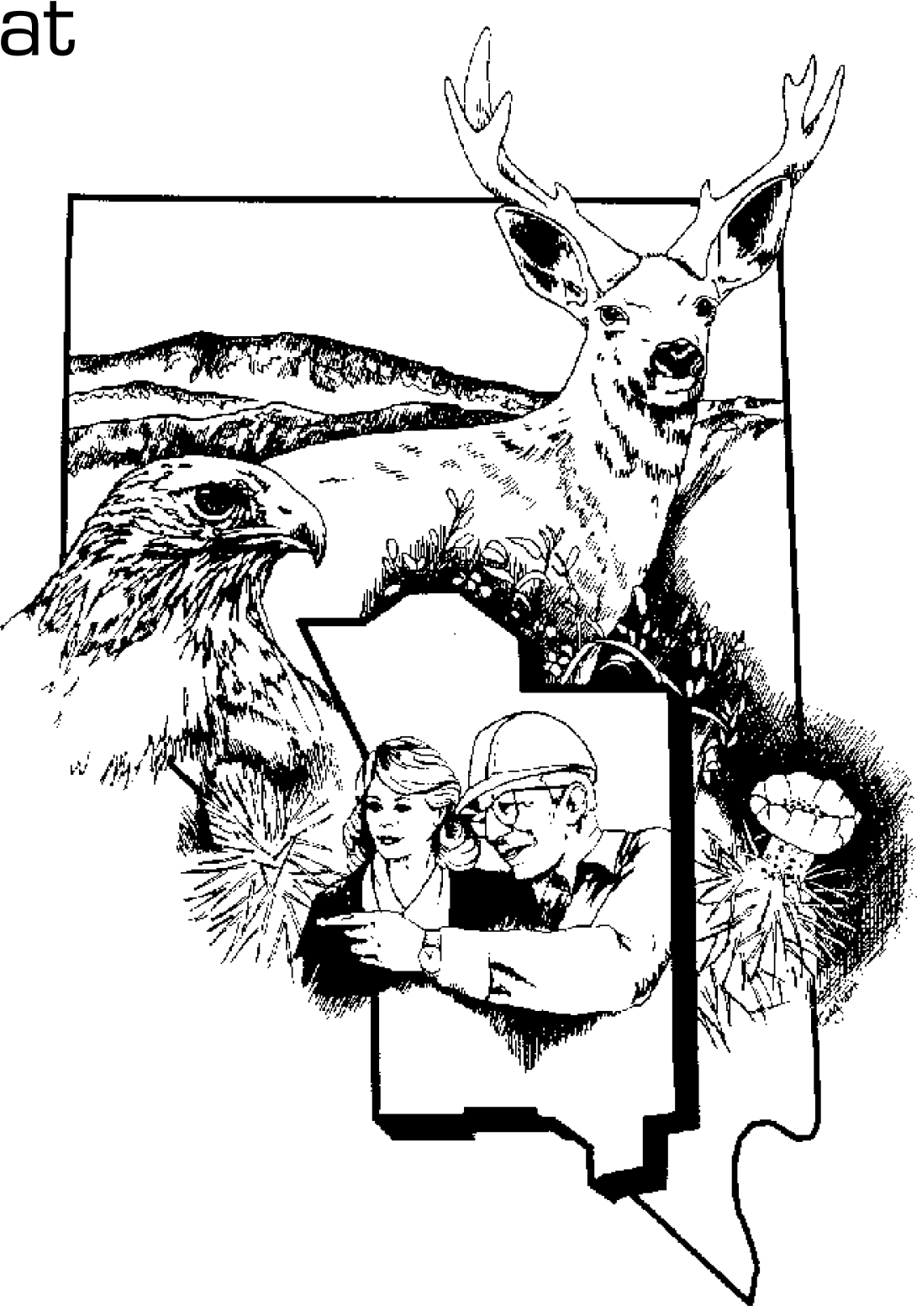

Approved for public release; further dissemination unlimited.

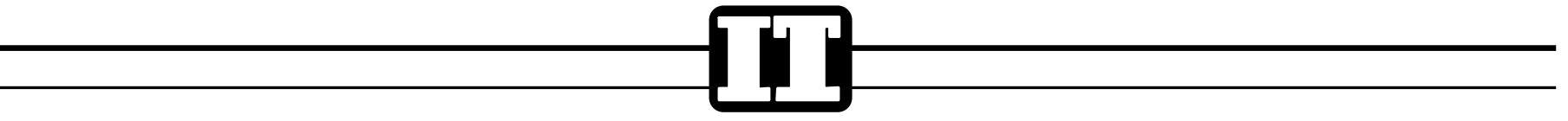




\title{
EVALUATION OF THE RULISON DRILLING EFFLUENT POND AS TROUT HABITAT
}

\author{
IT CORPORATION \\ 2621 Losee Road, Building B-1, Suite 3050-01 \\ North Las Vegas, Nevada 89030
}

February 1997

Approved for public release; further dissemination unlimited.

This work was performed for the U.S. Department of Energy by IT Corporation under Contract No.: DE-AC08-96NV10972 


\section{EVALUATION OF THE RULISON DRILLING EFFLUENT POND AS TROUT HABITAT}

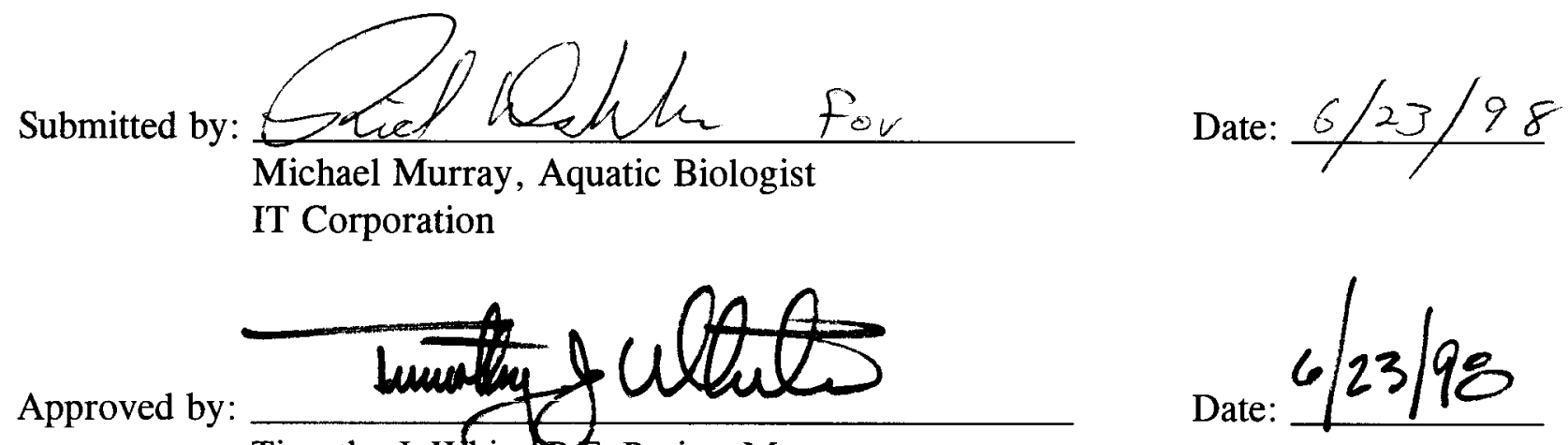

Timothy J. White P.E. Project Manager IT Las Vegas 


\section{Table of Contents}

List of Figures $\ldots \ldots \ldots \ldots \ldots \ldots \ldots \ldots \ldots \ldots \ldots \ldots \ldots \ldots \ldots \ldots \ldots \ldots \ldots \ldots$

List of Tables $\ldots \ldots \ldots \ldots \ldots \ldots \ldots \ldots \ldots \ldots \ldots \ldots \ldots \ldots \ldots \ldots \ldots \ldots \ldots \ldots$

List of Acronyms and Abbreviations $\ldots \ldots \ldots \ldots \ldots \ldots \ldots \ldots \ldots \ldots \ldots \ldots$ iii

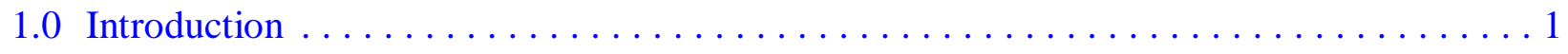

1.1 Site Background $\ldots \ldots \ldots \ldots \ldots \ldots \ldots \ldots \ldots \ldots \ldots \ldots \ldots \ldots \ldots \ldots \ldots \ldots \ldots$

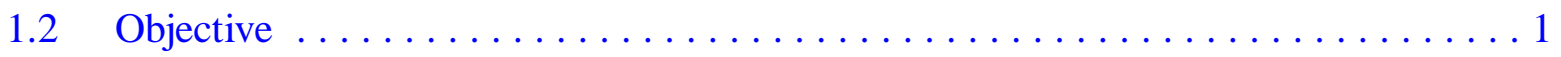

2.0 Methods . . . . . . . . . . . . . . . . . . . . . . . . . 2

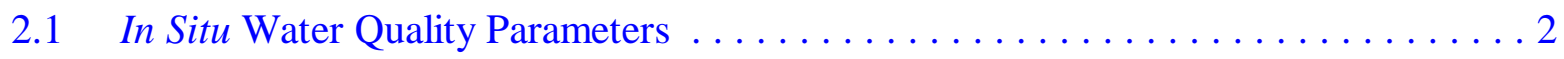

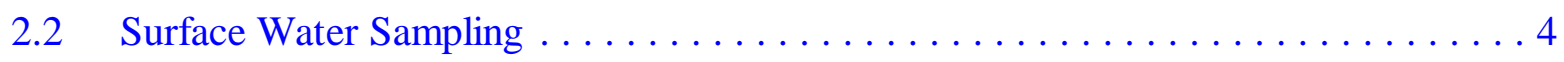

2.2.1 Trout Toxicity Test $\ldots \ldots \ldots \ldots \ldots \ldots \ldots \ldots \ldots \ldots \ldots \ldots \ldots \ldots \ldots \ldots \ldots \ldots \ldots \ldots$

2.3 Benthic Macroinvertebrate Sampling $\ldots \ldots \ldots \ldots \ldots \ldots \ldots \ldots \ldots \ldots$

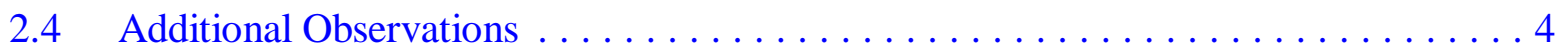

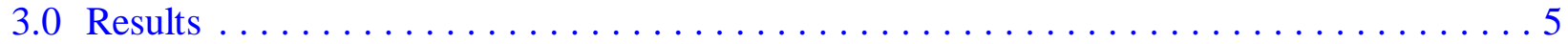

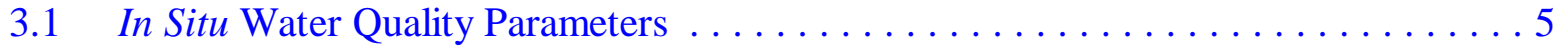

3.2 Benthic Macroinvertebrates - Bottom Grab Samples . . . . . . . . . . . . . . 5

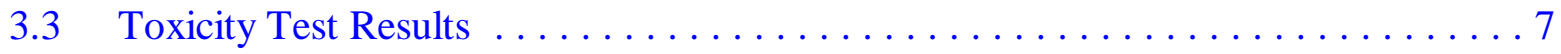

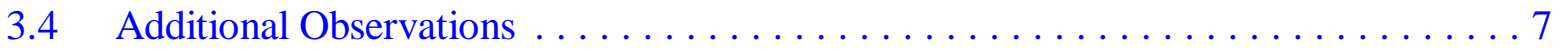

4.0 Conclusions and Recommendations $\ldots \ldots \ldots \ldots \ldots \ldots \ldots \ldots \ldots \ldots \ldots \ldots \ldots \ldots \ldots \ldots \ldots$

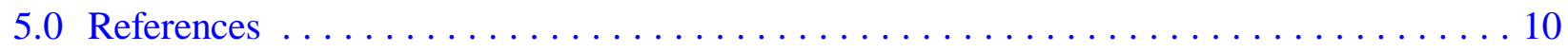




\section{List of Figures}

Number

Title

Page

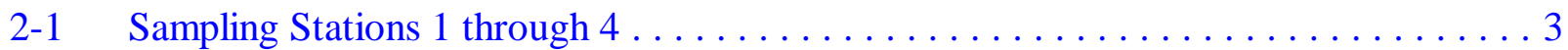

\section{List of Tables}

Number

Title

Page

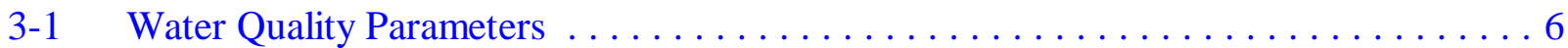

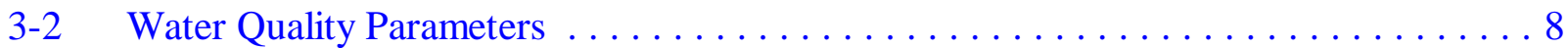




\section{List of Acronyms and Abbreviations}

$\begin{array}{ll}\text { DO } & \text { Dissolved oxygen concentration } \\ \text { DOE } & \text { U.S. Department of Energy } \\ \text { EPA } & \text { U.S. Environmental Protection Agency } \\ \mathrm{ft} & \text { Foot (feet) } \\ \mathrm{IT} & \text { IT Corporation } \\ \mathrm{km} & \text { Kilometer(s) } \\ \mathrm{in} . & \text { Inch(es) } \\ \mathrm{m} & \text { Meter(s) } \\ \mathrm{mg} / \mathrm{L} & \text { Milligram(s) per liter } \\ \mathrm{mi} & \text { Mile(s) } \\ \mathrm{mS} / \mathrm{cm} & \text { Millisiemen(s) per Centimeter } \\ \mathrm{mV} & \text { Millivolts } \\ \mathrm{SOP} & \text { Standard Operating Procedure } \\ \mathrm{TPH} & \text { Total petroleum hydrocarbon } \\ { }^{\circ} \mathrm{C} & \text { Degrees Celsius }\end{array}$




\subsection{Introduction}

\subsection{Site Background}

The Rulison Site is located in Section 25, township 7 South, Range 95 West, Garfield County, Colorado. The site is approximately 19 kilometers $(\mathrm{km})$ (12 miles [mi]) southwest of Rifle Colorado, and approximately $65 \mathrm{~km}$ (40 mi) northeast of Grand Junction, Colorado. Project Rulison was an experiment conducted jointly by the U.S. Atomic Energy Commission and Austral Oil Company to test the feasibility of using a nuclear device to increase natural gas production in low permeability geological formations. The experiment was conducted on September 10, 1969, and consisted of detonating a 43-kiloton nuclear device at a depth of 2,568 meters $(\mathrm{m})(8,426$ feet [ft]) below the ground surface (DOE, 1994).

The Rulison Drilling Effluent Pond (called "the pond") is an engineered structure covering approximately 0.2 hectare ( 0.5 acre), which was excavated and used to store drilling fluids during drilling of the device emplacement well. The drilling fluids consisted of bentonitic drilling mud with additives such as diesel fuel and chrome lignosulfonate. Most of the drilling muds were removed from the pond when the site was decommissioned in 1976, and the pond was subsequently stocked with rainbow trout by the land owner and used as a fishing pond. In 1994 and 1995, the U.S. Department of Energy (DOE) conducted sampling of the pond to evaluate residual contamination from the drilling fluids. Based on the results of this sampling, the DOE conducted a voluntary cleanup action in order to reduce the levels of total petroleum hydrocarbons and chromium in pond sediments. The cleanup was conducted between August and mid-November of 1995.

At the end of cleanup activities, the pond was lined with a clay geofabric and left dry. The geofabric was covered with sod to protect it. The pond has since been refilled by snowmelt and inflow from a spring. Prior to remediation, the pond apparently had sufficient water quality and food resources to support stocked rainbow trout.

\subsection{Objective}

The purpose of this investigation was to evaluate the present ecological status of the pond and to determine if post-remediation water quality and food resources are adequate to support stocked rainbow trout. Sampling of the pond was conducted by IT Corporation (IT) on September 10, 1996. 


\subsection{Methods}

Evaluation of the pond as trout habitat had three components:

- Measurement and evaluation of in situ water quality parameters

- Collection and evaluation of pond sediments for benthic invertebrates

- Collection of pond waters and subsequent performance of a laboratory toxicity test using juvenile rainbow trout

The methods used are described briefly in the following text.

\subsection{In Situ Water Quality Parameters}

Field parameters were measured using a Hydrolab Scout II multifunction water quality analyzer at four sampling stations described as follows:

Station 1 - in shallow water adjacent to the spring inflow to the pond

Station 2 - in deep water approximately $27 \mathrm{~m}(90 \mathrm{ft})$ toward the center of the pond from the spring inflow

Station 3 - in deep water approximately $30 \mathrm{~m} \mathrm{(100} \mathrm{ft)} \mathrm{toward} \mathrm{the} \mathrm{center} \mathrm{of} \mathrm{the} \mathrm{pond} \mathrm{from} \mathrm{the}$ pond outlet

Station 4 - in shallow water adjacent to the pond outlet

The water quality analyzer measured conductivity, temperature, $\mathrm{pH}$, oxidation reduction potential, and dissolved oxygen concentration (DO). In addition, total water depth at each sampling location was recorded as well as the depth at which the measurements were taken.

At Stations 1 and 4, measurements were taken at mid-depth. At Stations 3 and 4, measurements were taken $0.5 \mathrm{~m}$ (20 inches [in.]) above the bottom, at 1-m (3-ft) intervals through the water column and at the surface.

The locations of Sampling Stations 1 through 4, as well as the location where the water was collected for the laboratory toxicity test, are shown in Figure 2-1. 


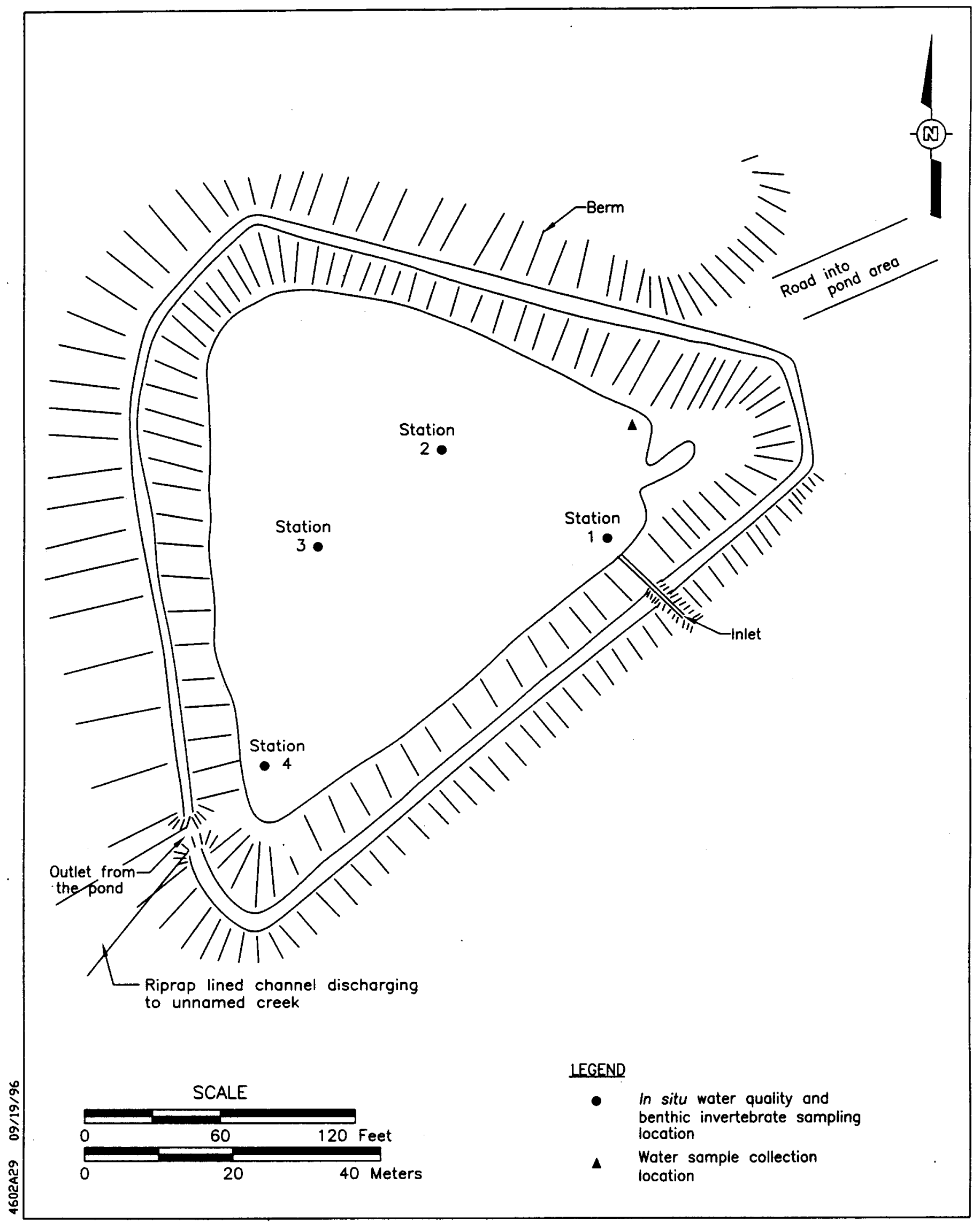

Figure 2-1

Sampling Stations 1 through 4 


\subsection{Surface Water Sampling}

Pond surface waters were collected to conduct a laboratory acute toxicity test on rainbow trout (Oncorhynchus mykiss). The water collection location was in shallow water adjacent to the pond

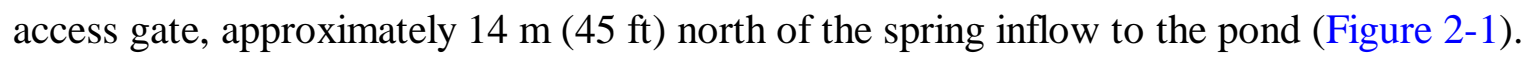
Four (2.5 gallon) cubitainers were filled by first submerging the containers directly in the pond and then completely filling the cubitainers using a decontaminated plastic beaker. During sample collection, care was taken to ensure that disturbed bottom sediments did not enter the sample containers. The samples were then packed with ice in coolers and shipped via overnight courier (Federal Express) to the IT Somerset, NJ, Toxicology Laboratory.

\subsubsection{Trout Toxicity Test}

The toxicity test was conducted in accordance with IT Aquatic Laboratory Standard Operating Procedure (SOP) No. 8.18.1 (IT, 1996) and current U.S. Environmental Protection Agency (EPA) protocols (EPA, 1993). The pond water sample was received by the laboratory on September 11, 1996. After measuring the hardness of the sample, reconstituted fresh water was prepared with a comparable hardness to use as the test control water. The rainbow trout, less than 30 days old, were then acclimated to the control water over a 48-hour period. The test was begun on September 13, 1996, by placing 10 randomly selected organisms from the acclimation chamber into each of the four replicate chambers of control and pond water. After 96 hours, the test was terminated, and final organism counts were made.

\subsection{Benthic Macroinvertebrate Sampling}

Pond sediment samples were collected at Stations 1 through 4 (locations described in Section 2.1) using a Ponar Dredge which samples an area of 0.052 square meters (81 square inches). Several grabs were taken at each location to ensure that the sediments examined were representative of the pond's benthic habitat. The dredge was cleaned between stations using a brush and site water rinse.

Upon retrieval, sediments were placed in prelabeled plastic buckets and transported to the shore of the pond for sieving to separate organisms and coarse material from fine sediments. Bethic invertebrates found in the sieves were removed and identified.

\subsection{Additional Observations}

In addition to the sampling already described, observations were made of the pond's flora and fauna. In situ water quality parameters were taken in the nearby unnamed creek and beaver pond 
for reference purposes. Also, photographs were taken of the sampling stations, sampling operations, and the sieved benthic samples.

\subsection{Results}

\subsection{In Situ Water Quality Parameters}

Water quality parameters collected at Stations 1 through 4 with the Hydrolab multifunction field instrument are shown in the following tables. Stations 1 and 4 measurements were taken at middepth; Stations 2 and 3 measurements were taken at $0.5 \mathrm{~m}$ (20 in.) above the bottom, at 1-m (3-ft) intervals through the water column, and at the surface (Table 3-1).

\section{Water Quality Criteria}

Water quality criteria for dissolved oxygen and $\mathrm{pH}$ are included here for comparison to the field data. Water quality criteria for the other measured parameters are not available. The data presented for dissolved oxygen are the cold water criteria which are the applicable criteria for the maintenance of a trout population. Since the desired goal is water quality sufficient to support stocked trout and trout reproduction in the pond is not expected, the dissolved oxygen criteria presented are for other than early life stages for trout.

Dissolved Oxygen Coldwater Criteria (EPA, 1986)

30-Day Mean Minimum: 6.5 milligrams per liter (mg/L)

7-Day Mean Minimum: $5.0 \mathrm{mg} / \mathrm{L}$

1-Day Minimum: $4.0 \mathrm{mg} / \mathrm{L}$

pH Criteria for Freshwater Aquatic Life (EPA, 1986)

Range: 6.5 to 9.0

\subsection{Benthic Macroinvertebrates - Bottom Grab Samples}

The benthic macroinvertebrate survey was qualitative and was intended to give an indication about the approximate composition and abundance of benthic invertebrates in the pond sediments. The results of this survey of sediments collected at the four sampling stations are described below. 
Table 3-1

Water Quality Parameters

\begin{tabular}{|c|c|c|c|c|c|c|}
\hline \multicolumn{7}{|c|}{ STATION 1 WATER QUALITY PARAMETERS } \\
Water Depth O.6 meters
\end{tabular}

${ }^{a}$ Meter(s)

begree(s) Celsius

${ }^{c}$ Millisiemens per centimeter

Milligram(s) per liter

Millivolt(s) 
Station 1 - The sample consisted largely of fibrous plant material with some clay content. Numerous Chironomids (midge larvae) were found in this sample. Most were red, indicating species that are adapted to survive in low oxygen environments. Three crane fly larvae (Tipulidae), two of which were the same species, were also found in the Station 1 sample. No other organisms were noted at this station.

Station 2 - This sample consisted of dead and decomposing grass sod. The majority of the material would not pass through the sieve, and it was necessary to examine the sample carefully with forceps in an attempt to locate benthic organisms. No organisms were found in this sample.

Station 3 - The Station 3 sample was similar to the sample collected at Station 2 (the other deep water station) in that it was comprised of dead sod, had a foul odor, and contained no organisms. The Station 3 sample contained a small amount of clay.

Station 4 - This sample also contained decaying sod along with some silty material. Chironomids were observed in this sample; a total of eighteen were counted with additional larvae likely embedded in the fibrous material. Most of the chironomids were red (low oxygen tolerant species) with several white species noted. No other benthic invertebrate taxa were found in the Station 4 sample.

\subsection{Toxicity Test Results}

All test organisms survived in both the control and pond water samples, and no observable adverse effects were noted. Therefore, No Measurable Acute Toxicity was reported for the test. It is interesting to note that despite the low dissolved oxygen levels found in the pond, during the laboratory test the dissolved oxygen saturation remained above 60 percent, and aeration of the test chambers was not necessary.

\subsection{Additional Observations}

A "walk around" observation of the pond revealed numerous water striders (Gerridae) skating on the pond's surface, and water boatmen (Corixidae) in the shallows. Filamentous algae was abundant near the shoreline, but rooted macrophytes were sparsely distributed. The inflow to the pond was very low volume, and cattail (Typha sp.) was present on dry soil up to six feet from the water's edge, indicating that the pond level had dropped considerably (approximately $0.8 \mathrm{~m}$ [2.5 ft]) in the weeks prior to the survey. The level of the pond was well below the outflow channel, so that no water exchange was taking place, resulting in a stagnant condition. The pond 
water was brownish in color, a likely indication of high dissolved organic content. In the waters collected for toxicity testing, numerous planktonic organisms were observed.

Also observed in the shallow water were numerous large (approximately 13-centimeters [5-in.]) salamanders. These were particularly abundant near the pond outlet where more than a dozen were counted in an area approximately $3 \mathrm{~m}$ by $3 \mathrm{~m}$ (10 ft by $10 \mathrm{ft}$ ). Although no salamanders were collected for examination, several observed at close range appeared to be tiger salamanders. The salamanders were also present in deeper water where they continuously surfaced to gulp air.

No fish were observed during sampling, and IT was informed by the landowner that none had been stocked in the pond since the cleanup operation.

Unnamed Creek and Beaver Pond - In order to provide data for comparison, in situ water quality parameters were measured in the unnamed creek adjacent to the pond and also in a nearby beaver pond. Creek measurements were taken in two locations, one upstream of the pond outflow and one downstream. These data are shown in Table 3-2.

Table 3-2

Water Quality Parameters

\begin{tabular}{|c|c|c|c|c|c|c|}
\hline \multicolumn{7}{|c|}{$\begin{array}{l}\text { UNNAMED CREEK } \\
\text { (Upstream of Rulison pond outflow) } \\
\text { Water Depth } 0.1 \text { meters }\end{array}$} \\
\hline $\begin{array}{l}\text { Measurement } \\
\text { Depth }(m)^{\mathrm{a}}\end{array}$ & $\begin{array}{l}\text { Temperature } \\
\left({ }^{\circ} \mathrm{C}\right)^{\mathrm{b}}\end{array}$ & $\begin{array}{l}\text { Conductivity } \\
(\mathrm{mS} / \mathrm{cm})^{\mathrm{C}}\end{array}$ & $\begin{array}{l}\text { Dis. Oxygen } \\
(\mathrm{mg} / \mathrm{L})^{\mathrm{d}}\end{array}$ & $\begin{array}{l}\text { DO Percent } \\
\text { Saturation }\end{array}$ & $\begin{array}{l}\text { pH } \\
\text { (Units) }\end{array}$ & $\begin{array}{l}\text { Redox } \\
(\mathrm{mV})^{\mathrm{e}}\end{array}$ \\
\hline 0.1 & 9.23 & 317 & 8.53 & 100 & 8.39 & 234 \\
\hline \multicolumn{7}{|c|}{$\begin{array}{l}\text { UNNAMED CREEK } \\
\text { (Downstream of Rulison pond outflow) } \\
\text { Water Depth } 0.1 \text { meters }\end{array}$} \\
\hline $\begin{array}{l}\text { Measurement } \\
\text { Depth }(\mathrm{m})\end{array}$ & $\begin{array}{c}\text { Temperature } \\
\left({ }^{\circ} \mathrm{C}\right)\end{array}$ & $\begin{array}{l}\text { Conductivity } \\
(\mathrm{mS} / \mathrm{cm})\end{array}$ & $\begin{array}{l}\text { Dis. Oxygen } \\
(\mathrm{mg} / \mathrm{L})\end{array}$ & $\begin{array}{l}\text { DO Percent } \\
\text { Saturation }\end{array}$ & $\begin{array}{l}\text { pH } \\
\text { (Units) }\end{array}$ & $\begin{array}{l}\text { Redox } \\
(\mathrm{mV})\end{array}$ \\
\hline 0.1 & 10.07 & 413 & 8.56 & 102.5 & 8.41 & 236 \\
\hline \multicolumn{7}{|c|}{$\begin{array}{c}\text { BEAVER POND } \\
\text { Water Depth } 0.2 \text { meters }\end{array}$} \\
\hline $\begin{array}{l}\text { Measurement } \\
\text { Depth }(\mathrm{m})\end{array}$ & $\begin{array}{c}\text { Temperature } \\
\left({ }^{\circ} \mathrm{C}\right)\end{array}$ & $\begin{array}{l}\text { Conductivity } \\
(\mathrm{mS} / \mathrm{cm})\end{array}$ & $\begin{array}{l}\text { Dis. Oxygen } \\
(\mathrm{mg} / \mathrm{L})\end{array}$ & $\begin{array}{l}\text { DO Percent } \\
\text { Saturation }\end{array}$ & $\begin{array}{l}\text { pH } \\
\text { (Units) }\end{array}$ & $\begin{array}{l}\text { Redox } \\
(\mathrm{mV})\end{array}$ \\
\hline 0.2 & 10.00 & 413 & 8.61 & 104.0 & 8.25 & 242 \\
\hline
\end{tabular}

a Meter(s)

${ }^{b}$ Degree(s) Celsius

CMillisiemens per centimeter

d Milligram(s) per liter

Millivolt(s) 


\subsection{Conclusions and Recommendations}

Based on the results of the survey described in this report, the following conclusions and recommendations are presented:

- In the short time period since cleanup, the pond has been recolonized by a number of aquatic plants and animals, including algae, cattails, several species of insects, and salamanders.

- Due to a very low rate of inflow, the pond has no visible water exchange and has become stagnant.

- On the day of the survey, the pond waters were warm and had very low levels of dissolved oxygen throughout the water column, including shallow waters which contained a significant amount of oxygen-producing algae.

- The decaying sod is very likely the primary cause of the reduced dissolved oxygen levels.

- At present dissolved oxygen levels, the pond would not support a trout population.

- Dissolved oxygen levels are likely to increase after the sod decomposes; this process may take two to three years.

- Increasing the rate of inflow so that the pond waters continually outflow creating water exchange and flushing should result in an increase in pond dissolved oxygen.

- The laboratory toxicity test using juvenile rainbow trout in oxygenated pond water resulted in 100 percent survival indicating that, with the exception of dissolved oxygen levels, the pond water is adequate for trout survival.

- The pond should not be stocked with trout until the minimum dissolved oxygen concentration (except for near bottom waters) is $4 \mathrm{mg} / \mathrm{L}$. 


\subsection{References}

DOE, see U.S. Department of Energy.

IT Corporation, Somerset. 1996. SOP No. 8.18.1, "Acute Toxicity Testing with Rainbow Trout, Oncorhynchus Mykiss, or Brook Trout, Salvelinus fontinalis, exposed to Aqueous Samples." Somerset, NJ.

EPA, see U.S. Environmental Protection Agency.

U.S. Environmental Protection Agency. 1986. Quality Criteria for Water, EPA 440/5-86-001. Washington, DC: Office of Water Regulations and Standards.

U.S. Environmental Protection Agency. 1993. Methods for Measuring the Acute Toxicity of Effluents and Receiving Waters to Freshwater and Marine Organisms, EPA/600/4-90/027F. Washington, DC.

U.S. Department of Energy. 1994. United States Nuclear Tests, July 1945 through September 1992, DOE/NV-209 (Rev. 14). 


\section{Distribution List}

\section{$\underline{\text { Copies }}$}

Janet Appenzeller-Wing

4

DOE/Nevada Operations Office

P.O. Box 98518, M/S 505

Las Vegas, Nevada 89193-8518

U.S. Department of Energy

Nevada Operations Office

Technical Information Resource Center

P.O. Box 98518

Las Vegas, Nevada 89193-8518

U.S. Department of Energy

Office of Scientific and Technical Information

175 Oak Ridge Turnpike

Post Office Box 62

Oak Ridge, Tennessee 37831

U.S. Department of Energy

Public Reading Room

P.O. Box 98521, M/S NLV040

Las Vegas, NV 89193-8521

Parachute Branch Library

Rulison Public Reading Room

244 Grand Valley Way

Parachute, Colorado 81635

Central Files

IT Corporation

2621 Losee Rd., Bldg. B-1, 3050-01

North Las Vegas, Nevada 89030 